International Journal of Engineering \& Technology, $7(2.10)(2018) 26-32$
International Journal of Engineering \& Technology
SPC
Website: www.sciencepubco.com/index.php/IJET
Research Paper

\title{
Towards extra-jurisdictional environmental management in combating transnational environmental crimes in Malaysia from a legal aspect
}

\author{
Hanim Kamaruddin ${ }^{1 *}$, Muhamad Azham Marwan ${ }^{1}$ \\ ${ }^{I}$ Faculty of Law, Universiti Kebangsaan Malaysia \\ *Corresponding author E-mail: hanim@ukm.edu.my
}

\begin{abstract}
Environmental deterioration in Southeast Asia region can be attributed to illegal logging and timber smuggling which contributes to deforestation, wildlife smuggling, black-market transactions in ozone-depleting substances and dumping of other forms of hazardous wastes and chemical, illegal open burning incidents that can lead to air pollution contributing to transnational impacts. Controlling activities that are taking place within one State resulting to environmental impacts in another State is not uncommon in environmental issues and thus, such activities are construed as environmental crimes at times. Hence, any illegal activities within another jurisdiction must be addressed efficiently as the conduct of such activities are becoming increasingly sophisticated and complex partly due to the nature of transnational activities that operate beyond national boundaries. This article will discuss transnational environmental crime in Malaysia and Southeast Asia region and assess the application of adopting extra-jurisdictional approach to combat transnational environmental crime by drawing the example from Singapore's experience of passing the Transboundary Haze Pollution Act 2014 to tackle challenges of haze pollution that are caused by activities in another State. The finding of this article suggests that extra-jurisdictional legislation is a common management tool in international law based on the international principle of territorial sovereign applies to conduct of a State within its territory. There seemed to be an exception that stems from a principle known as 'objective territoriality principle' under international law that allows another State to make claims against another State that commits environmental crime resulting to transnational impacts. The efficiency of extra-jurisdictional approach will be analysed based on Malaysia's experiences in tackling transnational environmental crimes by reviewing domestic policies, local legislations and relevant international agreements to ensure that environmental protection is sustained.
\end{abstract}

Keywords: Environment, Transnational, Crime, Malaysia, Extra-jurisdictional

\section{Introduction}

International environmental crime is a major activity in Southeast Asia which generates at least 90 billion USD per year [1]. To be precise, United Nations and The International Criminal Police Organization (Interpol) has reported USD \$91bn to USD \$258bn as the estimated figure of the value of crime in 2016. Prior to the estimated $26 \%$ spike since 2014 , there had been a $5-7 \%$ increase every year since 2006 in felonies including wildlife poaching, smuggling, illegal logging, minerals theft and toxic waste dumping. According to the joint report by the United Nation Environment Programme (UNEP) and Interpol [2], more than a quarter of the world's elephant population have been killed for their tusks in the last decade alone. As a result, the value of the black-market industry is now increasing to nearly two to three times the rate of the global economy [3].

In Southeast Asia, the haze pollution is often experienced especially during the dry season between March to October. According to Erik Meeijard [4], the haze problem which occurs regularly in Southeast Asia was deemed as the biggest environmental crime in $21^{\text {st }}$ century that led to a loss of USD $\$ 35$ billion in Indonesia alone in 1997-98 catastrophe. It was revealed that the Indonesian government has not taken serious steps to stop and control the fire and haze problem as a result of open burning activities in palm oil concessionaires [5] further worsened by the impracticality of some canals dug out in the peat soil to channel water to fires. Indonesia was declared in a state of emergency for a month but, there was no declaration of a national fire emergency on all television channels and there was an absence in deterring or penalizing any polluter [6]. Furthermore, the neighbouring countries affected by the haze pollution were left at their own devices where each country had to mobilise national disaster management to alleviate impacts of haze pollution.

The impact on the natural world as a result of environmental crimes, such as haze pollution, has been devastating. Efforts to stop the global crime wave have been frustrated by weak laws, illprepared security forces, corruption and chronic underfunding .The abovementioned report by UNEP and INTERPOL [7] argued that new laws are needed as well as sanctions at national and international levels, the disruption of overseas tax havens, and increased crime-fighting funds. 


\section{International cooperation}

International cooperation to tackle challenges posed by transnational crime was formed since 1923, where the International Criminal Police Organization (Interpol) with 176 existing member states providing cooperation for the exchange of information and assistance between police forces to combat transnational crime. In July 1995, the European Union (EU) formed EUROPOL as an attempt to combat transnational crime at the European level. In 1989, the G7 nations [8] established the Financial Action Task Force (FATF) to tackle money laundering and set up the Lyon Group to improve international cooperation against transnational crime. The FATF provides a comprehensive set of measures for an effective legal and institutional regime against moneylaundering and the financing of terrorism by providing call for the implementation of specific asset freezing, seizing and confiscation mechanisms at international level [9] that were adopted into the domestic laws of the ratifying States [10]. In addition, The United Nations (UN) has also established several organisations for similar purposes namely UN Commission on Crime Prevention and Criminal Justice and the Commission on Narcotic Drugs and conceived international conventions such as the 1988 UN Convention against Illicit Traffic in Narcotic Drugs and Psychotropic Substances. Moreover, the Naples Ministerial Conference on Organized Crime was organized in November 1994 which led to the Naples Political Declaration and Global Action Plan against Organized Transnational Crime [11].

In the ASEAN region, the Joint Communiqué of the Second ASEAN Ministerial Meeting on Transnational Crime (AMMTC), Yangon, Myanmar in 23 June 1999 was held to discuss issues related to transnational crime where it was described as ' $a$ nontraditional threat to security'. The ministers noted that it "was becoming more organized, diversified and pervasive, and thus posed a serious threat to the political, economic and social wellbeing of all nations, including the ASEAN Member Countries" [12]. The AMMTC adopted the ASEAN Plan of Action to Combat Transnational Crime that sought to extend collective efforts and consolidate regional cooperation and to advocate the exchange of information, legal cooperation, law enforcement, training, and institutional building. Moreover, the Second AMMTC established an institutional structure against transnational crime [13] where the interior ministers agreed that their meeting would supervise the activities of ASEAN Chiefs of Police (ASEANAPOL), ASEAN Senior Officials on Drug (ASOD), and the ASEAN DirectorsGeneral of Customs (ADGC) with the cooperation with ASEAN Senior Law Officials' Meeting (ASLOM) and the ASEAN Attorney Generals' Meeting. The ministers also decided to form a Senior Officials Meeting on Transnational Crime (SOMTEC) that would coordinate measures approved by the AMMTC and develop a work programme to carry out the plan of action. Finally, they decided in principle to set up an ASEAN Centre for Combating Transnational Crime (ACTC). The idea was proposed by the Philippines, which offered to host its facilities. The ACTC was expected to help implement the plan of action, propose regional strategies, collect data on legal matters, and promote intelligence sharing among the members [14].

The Philippine President Joseph Estrada then expressed his views on transnational crime at the 13th General Meeting of the Pacific Economic Cooperation Council in Manila in October 1999 which highlighted the concept of security to include terrorism, drug trafficking, money laundering, environmental degradation, human trafficking and others. He opined that these issues have "become security issues because they threaten the quality of life of our people, erode our development efforts, and limit the policy choices available to us" [15].

\section{Malaysian experience}

Malaysia plays an important part in combating transnational crime by participating actively in contributing and sharing of infor- mation in the Commission on Crime Prevention and Criminal Justice (CCPJ) and Commission on Narcotic Drugs (CND) and also at the regional level such as ASEAN Work Programme to combat terrorism and transnational organized crime. Malaysia condemns all acts, methods and practices of terrorism and transnational crimes which transcends national boundaries and demanding international actions in accordance with the Charter of the United Nations and international laws and principles [16]. There are at least 34 Acts related to the environmental matters and various regulations, rules and orders are passed to legislate environmental protection activities [17]

In relation, Malaysia has enacted Mutual Assistance In Criminal Matters Act 2002 [18] where the objective of the Act is to provide and obtain international assistance in criminal matters, including providing and obtaining evidence, arranging an investigation, the recovery, forfeiture and confiscation of the property, restraint of dealing, request of search and seizure, to locate the offender, tracing of proceeds of crimes and examination of things and premises [19]. However, this Act does not prevent the rendering of assistance through informal channels nor does it supersede other available cooperation mechanisms. For instance direct informal requests for assistance intra-enforcement agency are undertaken amongst counterpart agencies such as INTERPOL, Customs or the Financial Intelligence Unit of the Central Bank of Malaysia [20] . The illegal trade of endangered species across the boundaries are becoming rampant in Malaysia and the ASEAN region. Illegal wildlife trade includes live pets, hunting for trophies, fashion accessories, cultural artifacts, and ingredients for traditional medicines and wild meat for human consumption. A substantial portion of the global illegal wildlife trade, possibly the largest in the world, takes place in Asia [21]. Demand for illegal wildlife is also increasing in ASEAN and the region is regarded as a key supplier of wildlife products in the world [22]. In the case of Wong Keng Liang v Public Prosecutor [23], where Wong Keng Liang (known as Lizard King), was arrested at the Kuala Lumpur International Airport (KLIA) on $26^{\text {th }}$ August 2010 attempting to smuggle 95 Boa Constrictor snakes to Jakarta which is a form of illegal export of scheduled species under section 10(a) of the International Trade in Endangered Species Act 2008 [24]. On $6^{\text {th }}$ September 2010, the accused had then pleaded guilty to the charge was convicted and sentenced by the Magistrate's Court with six months' imprisonment and a fine of RM190000. Subsequent to this, the Deputy Public Prosecutor (DPP) had filed an appeal against the sentence imposed by the Magistrate's Court. The accused had been previously charged and pleaded guilty to 40 felony charges for trafficking in some of the most rare and endangered reptile species, was later sentenced by the Federal Court in San Francisco to 71 months of imprisonment and a fine of USD $\$ 60,000$. In this case, an Investigation Officer has sent a letter to the Department of Justice, United States of America to request for an informal assistance for transmission of the related documents and records where the same was provided to the Attorney General's Chambers of Malaysia by the US to be used in the criminal proceeding in Malaysia [25]. On $4^{\text {th }}$ November 2010, High Court decided on the appeal where the sentence against the offender was increased to 5 years imprisonment. The accused then appealed against the decision on the sentence imposed. On $22^{\text {nd }}$ February 2012, the Court of Appeal reduced the subject's jail term from five years to 17 and-a-half months. This decision only affirms that the extra jurisdictional laws on wildlife trafficking need to be coordinated at the international level and all information derived on any offenders must be made public so that the illegal activities of a prior offender can easily be detected and prevented.

Another environmental crime that can be seen in Malaysia is related to deforestation in Malaysia caused by illegal logging activities in Peninsular Malaysia where losses during the years from 2006 to 2016 was RM15.2 million. This was revealed by Deputy Natural Resources and Environment Minister, Hamim Samuri in the Dewan Negara, in reply to Senator S. Bagiam Ayem Perumal's question on losses incurred from illegal logging in the country [26]. During the same period, 256 illegal logging cases were recorded, 
with 229 arrests made in connection to them [27]. In Malaysia, forestry is protected by numerous legislations forest such as the National Forestry Act 1984, Environmental Quality Act1974 and Wood-Based Industries (State Legislatures Competency) Act of 1984. Other complementing statutes include the National Land Conservation Act of 1960, National Land Code of 1965, Protection of Wildlife Act of 1972, National Parks Act of 1980, National Environmental Policy and National Agricultural Policy. However, the lack of enforcement has made the laws ineffective. Forestry enforcement officers are small in numbers to supervise our vast forests which cover 58\% of Malaysian land mass. Besides that, multiplicity of enforcement agencies has also resulted in overlapping jurisdiction and confusion amongst them led to weakness in the implementation of legislation [28].

The industrial waste sector is another major source of environmental offence in Malaysia [29] where illegal importation and dumping of waste are strictly prohibited by The Department of Environment of Malaysia. Waste generators are allowed to export waste for recycling, recovery, or treatment with prior written approval from the importing state to discourage abuse of other nations' rights. On importation of used electrical and electronics equipment, Malaysia does allow such importations, provided the products are not older than three years from manufacturing date following the guideline policies for the classification of used electrical and electronic equipment in Malaysia 2008, revised 2010 [30]. In 2016, for example, there was an attempt to dump toxic mining waste in Malaysia and investigation by Director of Environment showed one of the vessels carrying eight containers or 177.12 tonnes of mining waste would reach Port Klang on the dawn of October $29^{\text {th }}$. Another vessel carrying at least 27 containers suspected of containing toxic waste would arrive in Malaysia on 4 November 2016 [31]. The attempt to unload the cargo was stopped as it could potentially cause environmental pollution, and Malaysians would otherwise have to suffer the financial consequences and the potential health risks such as cancer if the country's land and rivers are contaminated by arsenic and cadmium [32].

In relation to Malaysia's governance to tackling environmental crimes, the Environmental Quality Act (EQA) was enacted in 1974 as an attempt to managing the environment issues in Malaysia. This Act is an enabling piece of legislation relating to the "prevention, abatement, control of pollution and enhancement, and for the purposes connected therewith". It seeks to establish a balance between industrialization and the equally important goal of protecting the public health and welfare while preserving the natural resources. There are various strategies, including that of criminal sanction, being applied in dealing with pollution control and other environmental offences [33]. However, there is no legal provision that specifically deal with the offenders of transnational crimes. Section 1(1) states that the EQA is to apply to the whole of Malaysia' which suggests that any offender beyond Malaysia is not subjected to any provisions in EQA 1974 [34]. Thus, it would require an amendment by the Parliament to the Act to amend that section to include offence committed abroad, at least in matters of transnational crime done by Malaysian individuals or companies. Then, the provisions which prosecute the offender can be applied such as section 29A of the EQA 1974, which prohibits any person from allowing or causing open burning in the Malaysian soil However, the provision remains silent on operations or activities committed abroad that may result to haze pollution in Malaysia. The power to prosecute the offenders liable for environmental offences in Malaysia is well decided in the case of Tenggara Gugusan Holidays Sdn. Bhd. v. Public Prosecutor [35] where three types of people may be prosecuted for the offence committed, namely the "owner", "occupier" and "company director". The "occupier" is defined by the Act [36] as "a person in occupation or control of any premises; or in relation to premises where different parts of which are occupied by different persons in occupation or control of each part; or any vehicle, ship or aircraft". The "owner" of any ship means "the person registered as the owner of the ship; in the absence of registration, the person owning the ship; in the case of a ship owned by any country and operated by a company which in that country is registered as the ship's operator". "Owner" shall also include the country or the agent or trustee of any of the owners, or where the owner cannot be traced or has died, his legal personal representative [37].

The general criminal liabilities of corporate entities are embedded in Malaysia's Companies Act 2016, but the criminal corporate liabilities for environmental criminal offences only can be found in several environmental statutes, particularly, the Environmental Quality Act 1974 in which Section 43 imposing penalties to companies or firms which breach any provision in the law. It states that:-

"where an offence against this Act or any regulations made thereunder has been committed by a company, firm, society or other body of persons, any person who at the time of the commission of the offence was a director, chief executive officer, manager, or other similar officer or a partner of the company, firm, society or other body of persons or was purporting to act in such capacity, shall be deemed to be guilty of that offence unless he proves that the offence was committed without his consent or connivance and that he had exercised all such diligence as to prevent the commission of the offence as he ought to have exercised, having regard to the nature of his functions in that capacity and to all the circumstances".

To apply Section 43 most effectively is the need to prove the element of 'consent' or 'knowledge' on the part of the company to carry out the activity that is alleged to have pollute the environment. This requirement can be seen in the case of Pendakwa Raya v. Synenviro Sdn Bhd [38], the company directors were charged under Section 34B [39] of the EQA 1974 for accepting scheduled waste managed to raise a reasonable doubt that they did not have any knowledge or mens rea of the scheduled waste. For this reason, their appeal was allowed.

In the case of Public Prosecutor v. Cocolin Industries Sdn. Bhd. [40], the judge held that:-

“... for purpose of criminal prosecution, strict compliance of the mode of service is essential to ensure that the accused is fully aware of what he is required to do. This is a significant concept of natural justice and procedural fairness. If the court, for any reason, takes the view that proper notice had not been served and the accused was not aware of the said notice, even though the prosecution is able to demonstrate that they have complied with the provision of section 39(1), the court is entitled to rule that the prosecution has not established one of the vital ingredients of the offence. This is so because compliance of section 39(1) only raises a rebuttable presumption in law that the notice has been served. A presumption is an inference of fact, drawn from other known or proved facts. It is a rule of law under which the courts are authorized to draw a particular inference from a particular fact, unless and until the truth of such inference is disproved by other evidence..."

However, the above assertion is only applicable to instances where local pollution is caused by national entities, thus there seemed to be lacunae in the EQA 1974 or any other criminal laws in Malaysia that allows for extra-jurisdictional actions to be taken against parties that carry out activities in another country resulting to transboundary pollution or other forms of environmental crime. An example can be found in the transboundary haze pollution experienced in South East Asia in 1997-1998, 2002 and in 20142015 where Malaysia did not raise any serious intention to claim against Indonesia for harm, loss and suffering endured by Malaysia's affected citizen, economy and environmental habitat caused by open burning and haze that transcended into Malaysia's borders. This is mainly attributable to Malaysia's firm commitment to ASEAN's non-interference policy where diplomatic approach to any problems or disasters in ASEAN region is upheld. Indonesia had only ratified the 2002 ASEAN Agreement on Transboundary Haze Pollution (AATHP) [41] in 2014, thus suggesting that Indonesia viewed haze problem as a sovereign issue that should only 
be tackled and resolved through their legal governance. Besides, the objective of AATHP is to prevent and monitor transboundary haze pollution through national efforts and regional and international cooperation and hence, it has been contended that the Agreement is non-imposing in nature, reflecting and bound by the ASEAN's firm notion of the "non-interference" principle. The Agreement does not legally forbid certain types of conduct that cause open burning, nor does it include obligations for compensation. The Agreement did not address the State's liability on the haze pollution and without such measures, it is not possible to bring an action to Indonesia, or any corporation or individual responsible for haze [42]. Basically, the Agreement is a diplomatic document to acknowledge the problems of transboundary haze pollution that must be resolved by concerted efforts by all ASEAN nations without any indication to penalize any offenders causing the act.

The current environmental legal system in Malaysia does not provide for environmental liability for criminal acts committed abroad for non-respect of environmental rules, and therefore the act to impose penalties rests with the host country where the main offence was committed [43].

\section{Extra jurisdiction environmental law in ma- laysia?}

The term extra jurisdiction is defined as a nation state's conduct occurring outside its borders [44]. According to Nathan Smith, extra jurisdiction means the legal capability of a municipality to exercise authority beyond the boundaries of its incorporated area [45]. Article 1 of the European Convention on Human Rights (ECHR) states that ' $[\mathrm{t}]$ he High Contracting Parties shall secure to everyone within their jurisdiction the rights and freedoms defined in Section I of this Convention'. However, these words remain unsettled and controversial, for instance, in European Court of Human Rights as to whether the circumstances of extra jurisdiction may cover within the ambit of this provision [46].

Environmental problems are frequently "transboundary" in nature. However, states do not, as a general rule, attempt to extend their environmental laws to other states but do apply their environmental laws extraterritorially to "global commons," or areas that are not subject to the jurisdiction of any one state. This is normally practiced under international regimes [47].

In the case of Arrest Warrant of 11 April 2000 (Democratic Republic of the Congo $v$ Belgium), International Court of Justice held that [48]:-

"A gradual movement towards bases of jurisdiction other than territoriality can be discerned. This slow but steady shifting to a more extensive application of extraterritorial jurisdiction by States reflects the emergence of values which enjoy an everincreasing recognition in international society. One such value is the importance of the punishment of the perpetrators of international crimes. In this respect it is necessary to point out once again that this development ... has led to ... the recognition of other, non-territorially based grounds of national jurisdiction."

The extra jurisdiction issue is still controversial and often causes tensions between the States. It was argued that an action that infringes the sovereignty of other States, where the criminal action is actually being taken place outside of its borders may promote foreign policy objectives. Anthony Colangelo pointed out that, rather than being a restraint on state power, the incorporation of international law into national law can actually serve to expand the power of the nation state by providing a constitutional justification to legislate extraterritorially [49]. Chehtman also assessed the notion of extra jurisdictional legislation where he suggested that a state's power to punish an offender is only justified where the collective interests of individuals in that state have an interest in a system of laws being in force and enforced. He argues that some assertions of extraterritoriality may not be justified by a sufficient collective interest by the domestic population of the asserting state [50].

The most important feature of the extraterritorial jurisdiction is the transnational character [51]. According to Diane Orentlicher, transnational law is law made by more than one state, and specifically with the involvement of non-state actors [52]. It usually embodies the provisions within its domestic laws. Therefore, transnational crime incorporates the elements of both domestic and international law, which the author concludes that by 'dissolving traditional dichotomies between the two"5 [53]. Vaughan Lowe observes that, 'the limits of the legal competence of a State ... is to make, apply, and enforce rules of conduct upon persons' [54]. To simplify this, the jurisdiction is observed based on two types: territorial and extraterritorial. Jurisdiction is said to be extraterritorial when imposed by a State on a conduct occurring outside its borders [55]. For example, India and Italy are disputing their competing claims of jurisdiction in relation to the killing of two Indian fishermen by Italian naval officers near the coast of Kerala. Both Italy and India claim the right to hear the matter on the basis that both have relevant laws applying extraterritorially [56]. However, it was decided that the extraterritorial laws of states are valid under international law to the extent that they do not unduly infringe the sovereignty of other States [57].

In relation to the issue of sovereignty in international law, two approaches could be taken in addressing a question of territoriality. The first approach is seen in the case of SS Lotus [58], where one allows States to exercise jurisdiction as they see fit, unless there is a prohibitive rule to the contrary. The International Court of Justice notes that:-

"Far from laying down a general prohibition to the effect that states may not extend the application of their laws and the jurisdiction of their courts to persons, property and acts outside their territory, it leaves them in this respect a wide measure of discretion which is only limited to certain cases by prohibitive rules; as regards other cases, every State remains free to adopt the principles which it regards as best and most suitable [59].

Hence, a State cannot use coercive power to enforce its rules outside its territory. A State cannot use military force to compel another State to abide by its laws. In other words, a State cannot implement a legal measures such as penalties, fines, seizures, investigations, or demands for information to give extraterritorial effect to its rules. Stating the contrary would mean shattering the principle of sovereign equality of States.

The second approach reflects customary international law adopted by most States. Under this approach, States are not authorized to exercise their jurisdiction, unless they can rely on such permissive principles such as territoriality, nationality, protective, and universality principles [60]. The territoriality principle may be invoked where conduct either takes place within a nation's borders (subjective territoriality) or the effects of the conduct are felt within the nation's borders (objective territoriality). The nationality principle can be a ground to exercise jurisdiction where a state's citizen or corporation is either a victim (passive nationality) or a perpetrator (active nationality). The universality principle is kept for international crimes such as piracy, genocide and crimes against humanity and finally, the 'protective principle' and 'effects principle' dictate respectively that a state can assert jurisdiction over foreign conduct that threatens national security or that has effects within that state [61].

The effects principle has been well decided in the American case of US v ALCOA [62], where the court held that "any state may impose liabilities, even upon persons not within its allegiance, for conduct outside its borders that has consequences within its borders that the state reprehends". An American antitrust law namely the Sherman Act [63] is found to be applicable to foreign conduct which results to adverse economic effects on the United States. The court in Environmental Defense Fund v Massey [64] made the presumption against the extraterritorial application of U.S. laws in 
foreign nations to avoid conflict between U.S. laws and those other nations which could result in international discord. However, there are at least three general categories where the presumption against extraterritorial application of U.S. law does not apply: (1) when Congress clearly expressed intent for the statute to have extraterritorial application; (2) when failure to extend the scope of the statute will result in adverse effects in the U.S.; and (3) when the government conduct Congress seeks to regulate occurs within the U.S. or largely within the U.S. Hence, it was decided that the United States could exert some measure of legislative control over an otherwise sovereign-less land and their decision making processes is a legitimate exercise of Congress' territoriality-based jurisdiction, and did not raise extraterritoriality concern.

International conflicts may also arise in scenarios where large companies allow locals to burn on their lands such as instances where a large Indonesian companies often enter into arrangements with local communities to allow them to cultivate crops on the former's concessionaires. Such companies can be liable for example, under the Transboundary Haze Pollution Act 2014 passed by Singapore based on Section 8(2), which states that any entity, be it owner or occupier of the land, who "condones any conduct by another" [65]. The Transboundary Haze Pollution Act 2014 is designed for an extraterritorial application for environmental of fences committed in foreign soil but has affected Singapore's environment. As intended in the THPA 2014, the Director-General of Environmental Protection is empowered to issue a preventive measures notice to an entity "requiring it to do or refrain from doing anything specified by the Director-General in the notice for the purpose of preventing, reducing or controlling any haze pollution in Singapore" [66]. Under s 9(2), this "may include, but is not limited to, deploying fire-fighting personnel and to use any other reasonable methods to extinguish the fires outside Singapore, to discontinue or not commence any burning activities, or to submit to the Director-General any plan of action to extinguish or prevent the spread of fire on such land". However, there is a problem of enforcement of the jurisdiction - Singapore can prosecute only when the offenders make an entry into the country, thus making the enforcement of the law rather difficult [67].

In 2015, the Preventive Measures Notices were issued to six Indonesia-based companies requiring them to explain steps taken to extinguish and prevent fires on their land, pursuant to Section 9 of the THPA 2014. However, the imposed provision seemed to fail when only two (2) firms responded [68]. In addition, Singapore obtained a court warrant to summon the unnamed director of one of the four companies which did not reply and this drew a strong reaction from Indonesia, which issued a protest via its embassy in Singapore on $12^{\text {th }}$ May 2016 [69] and rejected requests from Singapore for access to information on errant companies [70].

In the ASEAN's context, the Bangkok Declaration is committed to any progress being made at regional and international levels concerning extraterritorial obligations. Such headway can be seen through the recent step taken by the UN Human Rights Council Resolution towards the establishment of a legally binding instrument to regulate the activities of transnational corporations and business enterprises [71]. Thus, ASEAN welcomes the support from among governments in the region to endorse the UN Human Rights Council Resolution on a legally binding instrument for transnational corporations' activities and consider it to be a critical step towards strengthening corporate accountability for human rights violations and ensuring access to justice for victims [72].

Hence, with positive development in extrajurisdictional governance at the international level, any acts of violation of environmental laws by any activities in a foreign country, in relation to preventing air pollution and its transboundary effects in the future for example, may prevent environmental crimes where non-state actors are made liable for their own actions, either under the laws of the host or home State. Hence, it is an opportune time that the law in Malaysia is reassessed and reviewed to ensure that any acts to comply with rules and regulations pertaining to environmental protection from environmental crimes committed abroad. Any mandatory strategies to be deployed including due diligence pro- cess, may ensure that any individuals or entities in another State are environmentally and socially responsible for their actions in the event these responsibilities are breached.

\section{Conclusion}

Many environmental issues are transboundary in nature and can only be addressed effectively through international cooperation. Furthermore, a sovereign has a right to exploit its natural resources or to undertake any activities construed as development and progress in their soil. However, that sovereign right is not unlimitless in that a state has the responsibility to ensure that activities that may lead to environmental crime within its jurisdiction or control do not cause damage to the environment of other states [73]. The environmental law in Malaysia needs to be revised to allow Malaysia to have an extra territorial jurisdiction, by taking an example of Singapore's approach in passing Transboundary Haze Pollution Act 2014, in allowing to take action against companies or entities in a foreign soil that cause air pollution to neighbouring countries. In addition, it is equally crucial to reexamine the content of the ASEAN Agreements in dealing with crime beyond the borders such as ASEAN Agreement on Transboundary Haze Pollution and Bangkok Declaration to ensure that these agreements are enforceable in the signatory States. It is therefore, necessary for the content of these Agreements to be revised especially in relation to control measures and enforcement based on international law principles of state liability and responsibility and international laws on objective territoriality principle by Malaysia to reaffirm environmental crime resolutions with neighbouring countries in South East Asia.

\section{Acknowledgement}

This work was supported Universiti Kebangsaan Malaysia (UKM) Research Grant GGPM-2016-073.

\section{References}

[1] United Nations Office on Drugs and Crime. Malaysia targeting corruption to fight environmental crimes. Available from: https://www.unodc.org/southeastasiaandpacific/en/2016/04/mal aysia-environmental-crimes/story.html. (Date of access: 29th January 2018).

[2] Nellemann C. (Editor in Chief); Henriksen R, Kreilhuber A, Stewart D, Kotsovou M, Raxter P, Mrema E \& Barrat S. (Eds) (2016), The Rise of Environmental Crime - A Growing Threat To Natural Resources Peace, Development And Security, A UNEPINTERPOL Rapid Response Assessment. United Nations Environment Programme and RHIPTO Rapid ResponseNorwegian Center for Global Analyses, 2016 at www.rhipto.org. (Date of access 11 December 2017).

[3] The Guardian (2016), Value of eco crimes soars by $26 \%$ with devastating impacts on natural world, 2016. Available from: https://www.theguardian.com/environment/2016/jun/03/valueeco-crimes-soars-26-with-devastating-impacts-natural-world. (Date of access: $29^{\text {th }}$ January 2018)

[4] Erik Meeijard (2015), Indonesia's Fire Crisis - The Biggest Environmental Crime of the 21st Century, Jakarta Globe, 2015. Available from: http://jakartaglobe.id/opinion/erik-meijaardindonesias-fire-crisis-biggest-environmental-crime-21stcentury/ . (Date of access: 30 $0^{\text {th }}$ January 2018)

[5] Helena Muhamad Varkkey (2011), Plantation Land Management, Fires and Haze in Southeast Asia, Malaysian Journal of Environmental Management 12(1), 2011, 35. Available from;jis.uum.edu.my/images/pdf/8jis/5theeasean.pdf (Date of access: 03/02/2018).

[6] Ibid.

[7] Erik Meeijard (2015), Indonesia's Fire Crisis - The Biggest Environmental Crime of the 21 st Century, Jakarta Globe, 2015.

[8] The Group of Seven Nations consist of: Canada, France, Germany, Italy, Japan, the United Kingdom, and the United States.

[9] United Nations Office on Drugs and Crime, UN Instruments and Other Relevant International Standards on MoneyLaundering and Terrorist Financing. Available from: 
https://www.unodc.org/unodc/en/money-

laundering/Instruments-Standards.html (Date of access: 3rd February 2018)

[10] Ibid.

[11] Emmers, Ralf (2002), The securitization of transnational crime in ASEAN, Singapore: Nanyang Technological University, 2002, p.3. Available from: http://hdl.handle.net/10220/4440. (Date of access: $31^{\text {st }}$ January2018)

[12] Ibid, p. 11.

[13] http://asean.org/managing-transnational-crime-in-asean-by-spushpanathan/ . (Date of access :28 January 2018)

[14] Ibid, p. 12.

[15] Speech by President Joseph Estrada at the 13th General Meeting of the Pacific Economic Cooperation Council, Manila, the Philippines, 21 October 1999. Available from: https://www.rsis.edu.sg/wp-content/uploads/rsispubs/WP39.pdf. (Date of access: 31 ${ }^{\text {st }}$ January 2018)

[16] Official Portal of Ministry of Foreign Affairs Malaysia, Transnational Crime, Wisma Putra. http://www.kln.gov.my/web/guest/transnational-crime (Date of access: $3^{\text {rd }}$ February 2018)

[17] Tan Sri Abdul Hamid Bin Embong, Federal Court Judge of Malaysia, Environmental Justice In Malaysia: Issues And Challenges, 2nd National Seminar On Environmental Justice, 15 18 October 2015, Belum Rainforest Resort, State Park, Grik, Perak, p. 3.

[18] Act 621 .

[19] Ibid, section 3.

[20] Ibid, section 4.

[21] Tan Sri Abdul Hamid Bin Embong, Federal Court Judge of Malaysia, Environmental Justice in Malaysia: Issues and Chal[22] Ibid lenges, 2nd National Seminar on Environmental Justice, p. 7.

[23] [2013] 1 CLJ 96; [2012] 1 LNS 244.

[24] Act 686 .

[25] Tan Sri Ahmad Maarop, Federal Court Judge of Malaysia, $M u$ tual Assistance In Responding To Transnational Environmental Challenges: Malaysian Experience, Fifth ASEAN Chief Justices' Roundtable On Environment ASEAN Judicial Cooperation On The Environment; The Proceedings Siem Reap, Cambodia, 4-5 December 2015. Available from: http://www.ajne.org/sites/default/files/event/7/sessionmaterials/final-1-mutual-assistance-in-responding-totransnational-environmental-challanges.pdf. (Date of access: $3^{\text {rd }}$ February 2018).

[26] Soo Wern Jun, Malaysia recorded RM15.2 million in losses due to illegal logging, New Straits Times, 2017. https://www.nst.com.my/news/nation/2017/08/268225/malaysi a-recorded-rm152-million-losses-due-illegal-logging . (Date of access 25 December 2018).

[27] Ibid.

[28] Tan Sri Abdul Hamid Bin Embong, Federal Court Judge of Malaysia, Environmental Justice in Malaysia: Issues and Challenges, 2nd National Seminar on Environmental Justice, p. 11.

[29] Ogboo Chikere Aja, Hussain H. Al-Kayiem, Mesfin Gizaw Zewge and Selowara Joo, Overview of Hazardous Waste Management Status in Malaysia, Management of Hazardous Wastes, Prof. Hosam El-Din Saleh (Ed.), InTech, DOI: 10.5772/63682, 2016. Available from: https://www.intechopen.com/books/management-of-hazardouswastes/overview-of-hazardous-waste-management-status-inmalaysia. Date of access: $3^{\text {rd }}$ February 2017).

[30] M. DOE, "Guidelines for the classification of used electrical and electronic equipment in Malaysia," M. Department of Statistics, Ed., ed. Kuala Lumpur, Malaysia: Economic Planning Unit, 2010.

[31] Malay Mail Online, Malaysia foils plans to dump 177 tonnes of toxic waste from Romania, 2016. Available from: http://www.themalaymailonline.com/malaysia/article/malaysiafoils-plans-to-dump-177-tonnes-of-toxic-waste-fromromania\#yBGLoHXQiCWP35tF.99. (Date of access: $3^{\text {rd }}$ February 2018)

[32] Ibid.

[33] Maizatun Mustafa \& Nurah Sabahiah Mohamed (2015), The Development of Environmental Crime and Sanction in Malaysia, European Scientific Journal September 11(25), 32.

[34] Tan Sri Ahmad Maarop, Federal Court Judge of Malaysia, Mutual Assistance In Responding To Transnational Environmental Challenges: Malaysian Experience, 2015

[35] [2003] 1MLJ 508 .
[36] Section 2 of the Environmental Quality Act 1974

[37] Ibid.

[38] [2012] 2MLJ 829

[39] The section forbid placing, deposit, etc., of scheduled wastes, where no person shall:-

a. place, deposit or dispose of, or cause or permit to place, deposit or dispose of, except at prescribed premises only, any scheduled wastes on land or into Malaysian waters;

b. receive or send, or cause or permit to be received or sent any scheduled wastes in or out of Malaysia; or

c. transit or cause or permit the transit of scheduled wastes, without any prior written approval of the Director General.

(2) The Director General may grant the written approval either subject to conditions or unconditionally.

(3) For the purpose of this Act, any act of receiving or sending, or transit of any scheduled wastes with an approval obtained through falsification, misrepresentation or fraud or which does not conform in a material way with the relevant documents in such form as may be prescribed, shall be an offence.

(4) Any person who contravenes this section shall be guilty of an offence and shall be liable to a fine not exceeding five hundred thousand ringgit or to imprisonment for a period not exceeding five years or to both.

[40] [2008] 8 CLJ 116.

[41] To date, the Agreement has been ratified by all ASEAN Member States. The Agreement requires the Parties to the Agreement to, among others, cooperate in developing and implementing measures to prevent, monitor, and mitigate transboundary haze pollution by controlling sources of land and/or forest fires, development of monitoring, assessment and early warning systems, exchange of information.

[42] Varkkey H (2015), The Haze Problem in Southeast Asia: Palm Oil and Patronage, Oxon: Routledge.

[43] Hanim Kamaruddin \& Cecep Aminuddin (2015), "Transboundary haze Polluters and Accountability: The legal landscape in Indonesia and Malaysia”, 18th International Academic Conference, London, p 337.

[44] Deborah Senz \& Hilary Charlesworth, 'Building Blocks: Australia's Response to Foreign Extraterritorial Legislation' (2001) 2 Melbourne Journal of International Law 69, 72; Jennifer A Zerk, 'Extraterritorial Jurisdiction: Lessons for the Business and Human Rights Sphere from Six Regulatory Areas' (Working Paper No 59, Harvard Corporate Social Responsibility Initiative, June 2010), p. 11, 13.

[45] Nathan Smith, Extraterritorial Jurisdiction (ETJ) - Is It Constitutional? January 15, 2013, Austin Tenant Advisors. Available from:

https://www.austintenantadvisors.com/blog/extraterritorialjurisdiction-etj-is-it-constitutional/ (Date of Access: $3^{\text {rd }}$ February 2018).

[46] Sarah Miller; Revisiting Extraterritorial Jurisdiction: A Territorial Justification for Extraterritorial Jurisdiction under the European Convention, European Journal of International Law, Volume 20, Issue 4, 1 November 2009, Pages 1223-1246. Available from: https://doi.org/10.1093/ejil/chp078. (Date of access: $3^{\text {rd }}$ February 2018)

[47] Zerk, Jennifer A, "Extraterritorial jurisdiction: lessons for the business and human rights sphere from six regulatory areas." Corporate Social Responsibility Initiative Working Paper No. 59. Cambridge, MA: John F. Kennedy School of Government, Harvard University, 2010, p. 176:-

For instance, under the international law of the sea, the "flag state" of a ship (i.e. the state in which a ship is registered or whose flag the ship is entitled to fly) has responsibility to regulate that ship effectively, which includes setting and enforcing standards designed to prevent marine pollution wherever that ship travels in the world. See further case study 16 below. And state parties to the 1959 Antarctic Treaty (and its 1991 Environmental Protocol) are required to regulate the impacts of their own nationals on the Antarctic environment, which includes the preparation of environmental impact assessments before any activities are carried out. Under the 1967 Outer Space Treaty, states must take steps to avoid harmful contamination of space, and generally conduct their activities with due regard for the interests of other states.

[48] [2002] ICJ Rep 3, 85.

[49] Anthony J Colangelo (2007), 'Constitutional Limits on Extraterritorial Jurisdiction: Terrorism and the Intersection of $\mathrm{Na}$ - 
tional and International Law'. 48 Harvard International Law Journal, 2007, p. 3, 122

[50] Alejandro Chehtman (2010), The Philosophical Foundations of Extraterritorial Punishment, Oxford University Press, pp. 589.

[51] Danielle Ireland-Piper (2012), Extraterritorial Criminal Jurisdiction: Does The Long Arm Of The Law Undermine The Rule Of Law? Extraterritorial Criminal Jurisdiction \& the Rule of Law, 24 Melbourne Journal of International Law 13, 2.

[52] Diane F Orentlicher (2007), 'Whose Justice? Reconciling Universal Jurisdiction with Democratic Principles' in Thomas J Biersteker et al (eds), International Law and International Relations, Routledge p. 207, 207.

[53] Ibid.

[54] Vaughan Lowe (2003), 'Jurisdiction' in Malcolm Evans (ed) International Law (Oxford University Press, 2nd ed,) 329, 329.

[55] Deborah Senz and Hilary Charlesworth, 'Building Blocks: Australia's Response to Foreign Extraterritorial Legislation' (2001) 2 Melbourne Journal of International Law 69, 72; Jennifer A Zerk, 'Extraterritorial Jurisdiction: Lessons for the Business and Human Rights Sphere from Six Regulatory Areas' (Working Paper No 59, Harvard Corporate Social Responsibility Initiative, June 2010) 13

[56] Jayanth Jacob, 'Italy, India in Tug of War over Trial', Hindustan Times (online), 20 February 2012 available from: http://www.hindustantimes.com/India-news/NewDelhi/ItalyIndia-in-tug-of-war-over-trial/Article1-814436.aspx>;

[57] Benjamin Perrin, 'Taking a Vacation from the Law? Extraterritorial Criminal Jurisdiction and Section 7(4.1) of the Criminal Code', 13 Canadian Criminal Law Review 175, 178; American Law Institute, Restatement (Third) of the Foreign Relations, 2009 , p. 180. Law of the United States (1987) $§ 101 \mathrm{cmt}$ (c); Liivoja,

[58] SS Lotus (France v Turkey) (Judgment) [1927] PCIJ (ser A) No 10.

[59] Ibid, p. 19

[60] Ibid

[61] Danielle Ireland-Piper, 2012. Extraterritorial Criminal Jurisdiction: Does The Long Arm Of The Law Undermine The Rule Of Law?, Extraterritorial Criminal Jurisdiction \& the Rule of Law, 24 Melbourne Journal of International Law [Vol 13], 136.

[62] 148 F.2d 416 (2d Cir. 1945).

[63] Enacted July, 1890.

[64] 986 F (2d) 528 (1993).

[65] For the purposes of this Act, where -

a. it is proved, or presumed by the operation of subsection (4), that an entity owns or occupies any land situated outside Singapore; and

b. it is further proved, or presumed by operation of subsection (1), that any haze pollution in Singapore involves smoke resulting from any fire on that land outside Singapore, it shall be presumed, until the contrary is proved, that the entity which is the owner or occupier of the land engaged in conduct, or engaged in conduct that condones any conduct by another, which caused or contributed to that haze pollution in Singapore

[66] Section 9, Transboundary Haze Pollution Act 2014

[67] Ryan Nicholas Hong (2016), Singapore's Transboundary Haze Pollution Act and the Shield of Sovereignty in Southeast Asia, 34 Sing. L. Rev. 103, HeinOnline, 2016, p. 124.

[68] Channel News Asia. NEA obtains court warrant against director of Indonesia firm who failed to aid with

[69] Channel News Asia, Saifulbahri Ismail, "Indonesia protests against Singapore's move to 'interrogate' company director" (12 May 2016). Available from: www.channelnewsasia.com/news/singapore/indonesiaprotests/2780446.html. (Date of access: $3^{\text {rd }}$ February 2018).

[70] Ryan Nicholas Hong, Singapore's Transboundary Haze Pollution Act and the Shield of Sovereignty in Southeast Asia, 2016, p. 118 .

[71] Article 12 of the Bangkok Declaration on Extraterritorial $\mathrm{Hu}$ man Rights Obligations.

[72] Ibid.

[73] S. Jayakumar, Tommy Koh, Transboundary haze law do permit extraterritorial jurisdiction in some cases, The Straits Time, $2016 . \quad$ Available from; http://www.asiaone.com/singapore/transboundary-haze-law-do- permit-extraterritorial-jurisdiction-some-cases. (Date of access : 25 January 2018 